\title{
Filmové adaptace ruské literatury jako transkulturní fenomén
}

\author{
BURRY, A. - WHITE, F. H. (eds): BORDER CROSSING: Russian Literature into Film. \\ Edinburgh: University Press, 2016, 298 s. ISBN 978-1-4744-1142-4.
}

V roce 2016 vydalo nakladatelství Edinburské univerzity sborník textů věnovaných světovým filmovým adaptacím klasických děl ruské literatury. Na první pohled by se mohlo zdát, že publikace je určená primárně oboru filmová studia, z bližšího seznámení je však patrné, že svým zaměřením překračuje obory a propojuje v sobě společenské, kulturní, historické a politické otázky Ruska a jejích reflexi v jiných kulturách. Spojovacím tématem totiž není pouze přepis literárního textu do filmového či sledování míry věrnosti mezi původním a nově vzniklým textem, jak filmové adaptace bývají nejčastěji hodnoceny. Již samotný název Border Crossing může napovědět, že autoři sborníku zvolili v pohledu na adaptaci jiný přístup a přenos originálního díla na filmové plátno vnímají z pohledu kulturního překročení hranic, ke kterému v textu dochází při jeho zasazení do odlišných prostorových či časových kontextů. Předložené studie tak otevírají diskusi ohledně vlivu zfilmovaného literárního díla na různé aspekty mezikulturní komunikace a jeho místa ve stěžejních bodech společenského vývoje.

Nový náhled na filmové adaptace vymezuje v úvodní kapitole Alexander Burry. Donedávna se studium této problematiky zakládalo jednak na zhodnocení míry věrnosti látky, jednak na hierarchické struktuře, kde pojmy „originál“ a „adaptace“ neumožňovaly nahlížet na obě díla stejně bez tendence je mezi sebou porovnávat. Tento přístup téměř vždy upřednostňoval originální dílo před jeho výslednou transformací do jiného média, kdy originál zůstával „hodnotícím standardem“ a jeho adaptace jen podřadnou a nedokonalou kopií. Na rozdíl od nejpopulárnějšího přístupu „kritiky věrnosti“ (fidelity criticism) editoři sborníku navrhují zkoumat složité vztahy literárního díla a jeho zfilmované podoby z kulturologického hlediska. Vztah literárního a filmového díla pak připomíná spíše kulturní dialog - původní význam zde ruského literárního díla musí být přizpůsoben pro odlišné teritorium (adaptování reálií pro místní publikum, přihlížení $\mathrm{k}$ jednotlivým lokálním konceptům v rámci pojetí díla atd.), čímž dochází k prolínání několika významových polí, které v celém procesu vede ke vzniku nových významů. Právě toto prolínání a křížení významů je reflektováno i v názvu a centrálním konceptu knihy „Border Crossing“.

Kniha je dále rozdělená do 11 kapitol, z nichž se každá věnuje konkrétní případové studii, čímž na jednu stranu usnadňuje kontakt s určitým dílem, jež čtenář vyhledává, 
ale zároveň také poukazuje na široké možnosti aplikovaného přístupu na vybraná díla $\mathrm{v}$ širokém časovém rozmezí a s různým místem vzniku. Tento př́stup ovšem také člení knihu na samostatné uzavřené texty a nehledě na společné základní téma mezi nimi vytváŕí jistý odstup. Autoři studií se navíc liší pojetím svých analýz. Některé př́spěvky jsou zaměřeny na porovnání více filmů ve vztahu jak k originálu, tak $\mathrm{k}$ jiným filmovým přepisům: např́íklad studie Ronalda Meyera se zaměřuje na více adaptací Dostojevského Bílých nocí a zkoumá vliv filmů na formování obecného povědomí o př́běhu; Yuri Leving se vydává směrem hledání intertextuálních odkazů a jejich interpretací v několika verzích Anny Kareniny. Další se soustředí pouze na jedno konkrétní dílo ve zvoleném kontextu: Olga Peters Hastyová a Sara Ceilidh Orrová analyzují ve svých studiích Kapsáře Roberta Bressona a režisérovu inspiraci díly Dostojevského nebo Alberta Camuse; Alexander Burry nabízí zajímavý pohled na modernizaci povídky Antona Pavloviče Čechova „Pavilon č. 6“ ve stejnojmenné adaptaci z roku 2009; Frederick $H$. White a Robert Mulcahy zkoumají přizpůsobení látky pro amerického diváka po zasazení literárního prríběhu do jiného časového a prostorového kontextu, jmenovitě v př́padě panpsychického dramatu Ten, $k d o$ dostává políčky a sovětské satiry Dvanáct křesel; a Dennis Ioffe analyzuje Nabokovovo Zoufalství ve Fassbinderově interpretaci po jeho přesazení do kulis nacistického Německa. Některá literární díla sice jsou považována za specifická pro určitou společnost (v tomto prrípadě většinou pro Rusko a Sovětský svaz), autoři ale dochází $\mathrm{k}$ závěru, že právě zasazením látky do jiného kulturního, časového či prostorového kontextu vzniká nový náhled na dílo, jež se ve filmové podobě osvobozuje od prostorových a časových hranic a odhaluje univerzálnost svého tématu. Mimo výše popsané kategorie stojí text Otto Boela, který dále otevírá téma zachování kulturní paměti skrze filmovou adaptaci povídky „Můj mladší bratr“ Vasilije Aksenova, její historické hodnoty a fungování jako „okna do minulosti“ a historického artefaktu.

Autorský kolektiv také poukazuje na to, že princip překročení hranic pro znovunalezení a odhalení nových významů umožňuje nahlížet z nové perspektivy nejen na adaptace literárních děl, ale i na tato díla samotná. Thomas Leitch uvádí ve svém textu metaforu Cristiny Della Colettaové, jež přirovnává způsoby transkulturního a transnárodního překročení hranic z geografického hlediska v podobě cestování $\mathrm{k}$ hermeneutickému hledisku při setkání diváka s jakoukoliv adaptací. Stejně jako při cestování se i odhalení nových zkušeností křriží s přehodnocením těch, které už známe - „nový horizont“ se tak skládá jak z nových znalostí a prožitků, tak z nového pohledu na ty staré. Hlavní idea knihy se vyznačuje novým pohledem na interkulturní komunikaci, vnáší originální př́stup v náhledu na kulturní hranice, jejich transformace, posouvání a samotnou existenci.

Stejně jako v jakékoliv publikaci tohoto typu se texty vyznačují nejen odlišným zaměřením, ale i různou kvalitou zpracování. Zatímco většině prríspěvků se daří 
přijít $s$ podnětnými myšlenkami a impulzy, text Yuriho Levinga $s$ př́značně př̀kombinovaným názvem „The Eye-deology of Trauma: Killing Anna Karenina Softly“ otevírá př́liš mnoho témat současně a nezřídka přichází s extrémními závěry, které nelze označit jinak než jako nadinterpretaci. Článek na př́íladu filmového zobrazení scény sebevraždy Anny Kareniny zkoumá vizuální hranice Tolstého hypotextu a jeho proměnu pod vlivem interpretačních teorií. Detailní záběr na Annino oko v posledních chvílích jejího života se např́íklad $\mathrm{v}$ autorově výkladu stává odkazem na Kino-oko Dzigy Vertova či slavný záběr z Buňuelova Andaluského psa, což ve spojení s dalším akcentovaným motivem ostrého předmětu reflektuje podle autora ženskou sexualitu a sebedestrukci. V podobném duchu autor nahližźi i na další aspekty Tolstého románu a jeho filmových adaptací a pokouší se $\mathrm{v}$ nich snad až př́liš samoúčelně odhalit překvapivé souvislosti.

Nehledě na jistou nesourodost a (očekávatelnou) kvalitativní nevyrovnanost považuji tuto publikaci za velice př́nosnou právě díky jejímu mezidisciplinárnímu charakteru, což má velký potenciál zejména v dnešní době, kdy křížení kultur nabývá na sile a vyžaduje tak nový pohled na mezikulturní komunikaci. Border Crossing totiž zaujme zejména svým celkovým přístupem než konkrétními eseji. Kniha má zároveň díky interkulturnímu dialogu, který otevírá a k němuž vybízí, potenciál oslovit odbornou veřejnost se zájmem o různé oblasti - od filmových a adaptačních studií až po slavistiku a literární vědu.

Ksenia Hainová

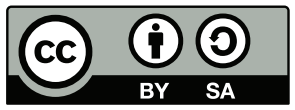

Toto dílo Ize užít v souladu s licenčními podmínkami Creative Commons BY-SA 4.0 International (<https:// creativecommons.org/licenses/by-sa/4.0/legalcode>). Uvedenése nevztahuje na díla či prvky (např. obrazovou či fotografickou dokumentaci), které jsou v díle užity na základě smluvní licence nebo výjimky či omezení príslušných práv. 